\title{
STATUS GIZI IBU HAMIL TRIMESTER III DI PUSKESMAS MANGASA KOTA MAKASSAR
}

\section{STATUS OF TRIMESTER III PREGNANT WOMEN AT PUBLIC HEALTH CENTRE MANGASA MAKASSAR CITY}

\author{
Subriah, Hidayati, Zulaeha A.Amdadi \\ Prodi D IV Kebidanan Makassar, Poltekkes Kemenkes Makassar
}

\begin{abstract}
ABSTRAK
Masalah gizi pada hakikatnya adalah masalah kesehatan masyarakat, namun penanggulangannya tidak dapat dilakukan dengan pendekatan medis dan pelayanan kesehatan saja. Penyebab timbulnya masalah gizi multifaktor. Oleh karena itu pendekatan pendekatan penanggulangannya harus melibatkan berbagai sektor yang terkait. Status gizi ibu hamil sangat mempengaruhi pertumbuhan janin dalam kandungan. Apabila status gizi ibu buruk, baik sebelum kehamilan dan selama kehamilan akan menyebabkan berat badan lahir rendah (BBLR). Disamping itu akan mengakibatkan terhambatnya pertumbuhan otak janin, anemia pada bayi baru lahir , bayi baru lahir mudah terinfeksi, abortus dan sebagainya. Jenis penelitian yang digunakan yaitu survey analitik dengan pendekatan Cross Sectional yang pengukurannya atau pengamatannya dilakukan secara simultan /sekali waktu, Lokasi Penelitian di Puskesmas Mangasa Kota Makassar yang akan dilakukan pada bulan Juli s/d Nopember 2018, Populasi penelitian ini adalah ibu hamil trimester III yang melakukan pemeriksaan antenatal care (ANC) di Puskesmas Mangasa Kota Makassar. Alat pengumpulan data yang digunakan berupa lembar kuisioner yang merupakan suatu daftar yang mengandung hubungan yang akan di teliti, mencakup pengetahuan ibu dan status gizi yang dipakai dengan menggunakan alat berupa pengukur tinggi badan, timbangan berat badan, dan pita LILA. Data diolah dan disajikan dalam bentuk table frekuensi dan narasi dan Analisis data yang akan digunakan untuk mencari hubungan antara variable independen dengan variable dependen, dengan menggunakan uji chiSquare dengan $\mathrm{Cl} 95 \%$. Hasil penelitian menunjukkan Ha diterima dimana nilai $p$-value $(0,00)<\alpha$-value $(0,05)$ dengan nilai phi $(\mu)$ $=0,658(66 \%)$ sehingga dapat diasumsikan bahwa terdapat hubungan pengetahuan dengan status gizi ibu hamil trimester III di Puskesmas Mangasa Kota Makassar
\end{abstract}

Kata Kunci :Ibu hamil Trimester III, Status Gizi Ibu hamil

\section{ABSTRACT}

Nutritional problems ae essentially a public health problem, but the response cannot be done with a medical approach and health service alone. The cause of the multifactor nutritional problem is that the approach to mitigation must involve various related sector that are related. The nutritional status of pregnant women greatly affects the growth of the fetus in the womb. Ifthe mother's nutritional status is bad, both before pregnancy and during pregnancy will cause low birth weight (LBW). Besides that it will result in inhibition of Fetal brain growth, anemia in newborns, newborns easily infected, abortion and so on. The type of research used is an analytical survey with a Cross Sectional approach whose meansurements or observations are carried out simultaneously/once at a time. Research sites at the Mangasa Health Center in Makassar City which will be conducted from July to November 2018. The research population is trimester III pregnant women do antenatal care (ANC) at Mangasa Health Center, Makassar City. The data collection tool used in the form of a questionnaire sheet which is a list containing the relationship that will be examined, including maternal knowledge and nutritional status used by using a tool in the form of height, weight scales, and LILA tape. Data is processed and presented in the form of frequency tables and narratives and data analysis will be used to find the relationship between the independent variables and the dependent variable, using the chi-square test with $95 \% \mathrm{Cl}$. The results showed that Ha was accepted where the $p$-value $(0,00)<\alpha$-value $(0,05)$ with the value of phi $(\mu)=0,658(66 \%)$ so that it can be assumed that there is a relationship between knowledge with nutritional status of pregnant women at the Mangasa Health Center of Makassar City.

Keywords : Pregnant Women Trimester III, Nutritional Status Pregnant Women

\section{PENDAHULUAN}

Masalah gizi pada hakikatnya adalah masalah kesehatan masyarakat, namun penanggulangannya tidak dapat dilakukan dengan pendekatan medis dan pelayanan kesehatan saja. Penyebab timbulnya masalah gizi multifaktor. Oleh karena itu pendekatan pendekatan penanggulangannya harus melibatkan berbagai sektor yang terkait (Supariasa, dkk, 2012).
Menurut World Health Organization(2008) prevalensi anemia gizi besi pada ibu hamil di dunia adalah sebesar $41,8 \%$, dengan prevelensi tertinggi adalah Afrika yaitu sebeasar $57,1 \%$ dan Asia sebesar 48,2\%, Amerika 24,1\%, Eropa $25,1 \%$. Status gizi di Indonesia terutama gizi ibu hamil khususnya kurang energi kronik (KEK) dan Anemia Gizi Besi, prevalensi KEK pada wanita hamil secara nasional adalah $24,2 \%$ (Riskesdas, 2013). Prevelensi ibu hamil resiko KEK di 
Sulawesi selatan sebanyak 78,7\% (Profil Kesehatan Sulsel, 2017), berdasarkan data rekam medik Puskesmas Mangasa jumlah ibu hamil pada bulan Januari s.d. Juni 2018 sebanyak 513 orang.

Kekurangan Energi Kronik merupakan kondisi yang disebabkan karena adanya ketidakseimbangan asupan gizi antara energi dan protein, sehingga zat gizi yang dibutuhkan tubuh tidak tercukupi. Ibu hamil yang menderita KEK mempunyai resiko melahirkan bayi dengan BBLR (Istiqomah, 2013).

Status gizi ibu hamil sangat mempengaruhi pertumbuhan janin dalam kandungan. Apabila status gizi ibu buruk, baik sebelum kehamilan dan selama kehamilan akan memyebabkan berat badan lahir rendah (BBLR). Disamping itu akan mengakibatkan terhambatnya pertumbuhan otak janin, anemia pada bayi baru lahir , bayi baru lahir mudah terinfeksi, abortus dan sebagainya (Supariasa, 2012).

Menurut Notoatmodjo pada tahun 2012 pengetahuan adalah hasil dari tahu, dan ini teradi setelah orang melakukan penginderaan manusia terhadap suatu objek tertentu.Pengetahuan atau kognitif merupakan domain yang sangat penting dalam membentuk tindakan seseorang.

Pengetahuan gizi merupakan pengetahuan tentang hubungan konsumsi makanan dengan kesehatan tubuh. Ibu hamil dengan pengetahuan gizi baik diharapkan dapat memilih asupan makanan yang bernilai gizi baik dan seimbang bagi dirinya sendiri beserta janin dan keluarga, dengan pengetahuan gizi yang cukup dapat membantu seseorang belajar bagaimana menyimpan, mengolah serta menggunakan bahan makanan yang berkualitas untuk di konsumsi menurut kebutuhannya (Sukmawati, 2012).

Hasil penelitian Sukmawati (2012) diketahui bahwa ada hubungan pengetahuan ibu hamil dalam memenuhi kebutuhan nutrisi terhadap status gizi ibu hamil. Ibu yang mepunyai pengetahuan tinggidengan status gizi baik sebanyak 29 (85,3\%) responden, sedangkan ibu hamil yang mempunyai pengetahuan kurang dengan status gizi kurang sebanyak 6 (54,5\%) responden. Disimpulkan bahwa apabila pengetahuan tentang gizi baik maka ibu hamil mempunyai status gizi baik.

Berdasarkan uraian diatas, maka peneliti tertarik untuk melakukan penelitian dengan judul Hubungan Pengetahuan dengan Status Gizi lbu
Hamil Trimester III di Puskesmas Mangasa Kota Makassar.

\section{METODE PENELITIAN}

Jenis penelitian yang digunakan yaitu survey analitik dengan pendekatan Cross Sectional yang pengukurannya atau pengamatannya dilakukan secara simultan / sekali waktu, Lokasi Penelitian di Puskesmas Mangasa Kota Makassar yang akan dilakukan pada bulan Juli s/d Nopember 2018, Populasi penelitian ini adalah ibu hamil trimester III yang melakukan pemeriksaan antenatal care (ANC) di Puskesmas Mangasa Kota Makassar. Alat pengumpulan data yang digunakan berupa lembar kuisioner yang merupakan suatu daftar yang mengandung hubungan yang akan di teliti, mencakup pengetahuan ibu dan status gizi yang dipakai dengan menggunakan alat berupa pengukur tinggi badan, timbangan berat badan, dan pita LILA. Data diolah dan disajikan dalam bentuk table frekuensi dan narasi dan Analisis data yang akan digunakan untuk mencari hubungan antara variable independen dengan variable dependen, dengan menggunakan uji chiSquare dengan $\mathrm{Cl}$ 95\%.

\section{HASIL}

Karakteristik responden dalam penelitian ini adalah umur, Pendidikan dan Paritas. Hasil Penelitian menunjukkan bahwa distribusi tertinggi pada umur 26-35 tahun yaitu sebanyak 50 responden $(33,3 \%)$ dan responden terendah pada umur 36-45 tahun sebanyak 6 responden $(17,54 \%)$, sedangkan pada tingkat pendidikan responden yang tertinggi pada tingkat pendidikan SMA yaitu 49 responden $(58,3 \%)$ dan terendah pada tingkat pendidikan $\$ 1$ yaitu 6 responden $(7,1 \%)$. Dan responden pada tingkat paritas, tertinggi pada tingkat Paritas 0 yaitu 33 responden $(39,3 \%)$ dan terendah pada tingkat paritas 4 dan 6 yaitu masing-masing 1 responden $(1,2 \%)$.

Distribusi frekuensi pengetahuan dengan status gizi ibu hamil trimester III menunjukkan bahwa dari 84 ibu hamil trimester III di Puskesmas Mangasa Kota Makassar yang memiliki pengetahuan baik sebanyak 36 ibu hamil trimester III (42,9\%) dan pengetahuan yang kurang sebanyak 48 ibu hamil trimester III $(57,1 \%)$, Distribusi frekuensi status gizi ibu hamil trimester III menunjukkan bahwa dari 84 ibu hamil trimester III di Puskesmas Mangasa Kota 
Makassar terdapat 34 ibu hamil trimester III $(40,5 \%)$ dengan status gizi normal dan 50 ibu hamil trimester III $(50,5 \%)$ dengan status gizi tidak normal

Distribusi hubungan pengetahuan dengan status gizi ibu hamil trimester III di Puskemas Magasa Kota Makassar menunjukkan bahwa ibu hamil trimester III yang memiliki pengetahuan yang baik sebanyak 36 responden. Dari 36 responden, terdapat 28 responden $(77,8 \%)$ yang memiliki status gizi normal dan 9 responden $(22,2 \%)$ yang memiliki status gizi tidak normal. Sedangkan ibu hamil trimester III yang memiliki pengetahuan kurang yaitu sebanyak 48 responden. Dari 48 responden, terdapat 6 responden $(12,5 \%)$ yang memiliki status gizi normal dan 42 responden $(87,5 \%)$ yang memiliki status gizi normal.

Setelah dilakukan analisis Chi-Square dengan tingkat kepercayaan $95 \%$ diperoleh nilai $p$-value 0,00 yang berarti lebih kecil dari $\alpha$-value $(0,05)$. Dengan demikian dapat dinyatakan bahwa terdapat hubungan yang bermakna antara pengetahuan dengan status gizi ibu hamil trimester III di Puskesmas Mangasa Kota Makassar.

Untuk mengetahui kekuatan hubungan antara variabel tersebut maka dilakukan uji asosiasi (phi). Dan diperoleh nilai phi $(\mu)=0,658$ dengan persentase $66 \%$, sehingga dapat diinterpretasikan bahwa kekuatan hubungan antara pengetahuan dengan kelengkapan imunisasi TT adalah kuat.

\section{PEMBAHASAN}

Berdasarkan hasil penelitian menunjukkan bahwa sebagian besar umur ibu antara 20-35 tahun. Menurut Winkjosastro (2009), umur 26-35 termasuk dalam umur reproduksi sehat. Sebagian besar pendidikan yang tertinggi pada SMA yaitu 49 orang $(58,3 \%)$. Menurut Soekanto (2012) bahwa salah satu faktor yang mempengaruhi pengetahuan adalah pendidikan. Pendidikan adalah suatu proses belajar yang berarti di dalam pendidikan itu terjadi proses pertumbuhan, perkembangan atau perubahan ke arah yang lebih dewasa, lebih baik dan lebih matang terhadap individu, kelompok atau masyarakat. Berdasarkan paritas ibu, terbanyak di Paritas 0. Tingkat pengetahuan ibu hamil tentang gizi terdapat 36 responden $(42,9 \%)$ memiliki pengetahuan baik dan dipandang dari segi pendidikan 2 responden SD, 8 responden SMP, 21 responden SMA, 2 responden Diploma
III dan 3 responden S1. Hal ini dimungkinkan semakin tinggi pendidikan semakin baik akses informasi.

Berdasarkan hasil penelitian terlihat bahwa pengetahuan merupakan salah satu faktor yang berhubungan dengan status gizi ibu hamil Trimester III. Diasumsikan demikian karena setelah dilakukan analisis Chi-Square ChiSquare dengan tingkat kepercayaan 95\% diperoleh nilai $p$-value 0,00 yang berarti lebih kecil dari $\alpha$-value $(0,05)$. Sehingga dapat dinyatakan bahwa terdapat hubungan yang bermakna antara pengetahuan dengan status gizi ibu hamil trimester III di Puskesmas Mangasa Kota Makassar. Hasil uji Chi-Square diatas menunjukkan bahwa terdapat hubungan yang bermakna antara variabel. Untuk mengetahui kekuatan hubungan antara variabel tersebut maka dilakukan uji asosiasi (phi). Dan diperoleh nilai phi $(\mu)=0,658$ dengan persentase $66 \%$, sehingga dapat diinterpretasikan bahwa kekuatan hubungan antara pengetahuan dengan status gizi ibu hamil Trimester III adalah kuat.

Hasil penelitian ini sejalan dengan hasil penelitian yang dilakukan oleh Sukmawati (2012) diketahui bahwa ada hubungan pengetahuan ibu hamil dalam memenuhi kebutuhan nutrisi terhadap status gizi ibu hamil. Ibu yang mepunyai pengetahuan tinggi dengan status gizi baik sebanyak $29(85,3 \%)$ responden, sedangkan ibu hamil yang mempunyai pengetahuan kurang dengan status gizi kurang sebanyak 6 (54,5\%) responden. Pengetahuan merupakan hasil dari tahu dan ini terjadi setelah orang melakukan pengindraan terhadap suatu objek tertentu. Pengindraan terjadi melalui pancaindra manusia, yakni indra penglihatan, pendengaran, penciuman, rasa dan raba. Sebagian besar pengetahuan manusia diperoleh melalui mata dan telinga (Notoatmodjo S, 2012). Pengetahuan tentang status gizi ibu hamil adalah bagian dari upaya untuk mengoptimalkan kemampuan ibu, sehingga dengan pengetahuan gizi yang baik diharapkan ibu hamil trimester III memiliki status gizi yang baik pula.

Berdasarkan pembahasan diatas maka dapat ditarik kesimpulan sementara yakni terdapat hubungan yang bermakna antara pengetahuan dengan status gizi ibu hamil Trimester III di Puskesmas Mangasa Kota Makassar, ditandai dengan $p$-value $=0,00$ dan kekuatan hubungan antara kedua variabel adalah kuat dengan persentase $66 \%$. 


\section{KESIMPULAN}

Karakteristik ibu hamil trimester III bahwa responden tertinggi pada umur 26-35 tahun yaitu sebanyak 50 responden $(59,5 \%)$ dan responden terendah pada umur 36-45 tahun sebanyak 6 responden $(17,54 \%)$, sedangkan pada tingkat pendidikan responden yang tertinggi pada tingkat pendidikan SMA yaitu 49 orang $(58,3 \%)$. dan terendah pada tingkat pendidikan D3 yaitu 2 responden $(2,4 \%)$. Dan responden pada tingkat paritas, paritas 0 yang tertinggi 33 responden $(39,3 \%)$ dan terendah pada ibu dengan paritas 4 dan 6 yaitu 1 responden (1,2\%). Pengetahuan merupakan salah satu faktor penentu untuk status gizi ibu hamil Trimester III di Puskesmas Mangasa Kota Makassar, ditandai dengan hasil uji Chisquare dengan $p$-value $=0,00$ dan kekuatan hubungan antara kedua variabel adalah kuat dengan persentase $66 \%$.

\section{UCAPAN TERIMA KASIH}

Penulis mengucakan terima kasih dan penghargaan kepada Dipa Poltekes, Politeknik Kesehatan Kemenkes RI Makassar Jurusan Kebidanan, Puskesmas Mangasa Makassar yang telah mengizinkan penelitian dengan hasil yang dapat digunakan untuk publikasi bersama

\section{DAFTAR PUSTAKA}

Agria RIntan, dkk. 2012. Gizi Reproduksi. Fitramaya. Yogyakarta.

Ali Khomsan, 2010. Pangan Dan Gizi Untu Kesehatan. PT Rajagrafindo persada, Jakarta.
Dinas Kesehatan provinsi Sulawesi selatan 2017. Profil kesehatan provinsi sulawesi selatan 2014. Makassar.

Hasnah M. Noor dan Asmawati Gasma. 2017. Metode Penelitian Dan Statistik Dasar.Unit Penelitian Poltekes Makassar. Makassar

Kuswanti, Ina. 2014. Asuhan Kehamilan. Pustaka Pelajar. Yogyakarta.

Notoatmodjo, Soekidjo. 2012. Promosi Kesehatan Dan Perilaku Kesehatan. Rineka Cipta. Jakarta.

Prawirohardjo, Sarwono. 2014. Ilmu Kebidanan. PT Bina Pustaka Sarwono Prawirohardjo. Jakarta

Sri Astuti, dkk. 2017. Asuhan Ibu dalam Masa Kehamilan Buku Ajar Kebidanan-Antenatal Care (ANC). Penerbit Erlangga. Jakarta.

Sukmawati. 2012. Hubungan Antara Pengetahuan dan Sikap Dalam Memenuhi Kebutuhan Nutrisi Dengan Status Gizi Ibu Hamil Di Puskesmas Mangasa. http://repositori.uin-alauddin.ac.id/4836/ 1/Sukmawati.pdfDiakses 2 Juli 2018)

Supariasa I Dewa Nyoman, dkk. 2012, Penilaian Status Gizi. Penerbit Buku Kedokteran EGC, Jakarta

Sutanto,Vita Andina dan Fitriana, Yuni. 2014. Asuhan Pada Kehamilan (Panduan Lengkap Asuhan Selama Kehamilan Bagi Praktisi Kebidanan). Pustaka Baru Press. Yogyakarta. 


\section{LAMPIRAN}

Tabel 5.1 Karakteristik responden berdasarkan umur, pendidikan dan paritas Di Puskesmas Mangasa Kota Makassar

\begin{tabular}{lcc}
\hline Umur & Frekuensi (n) & Persen (\%) \\
\hline $15-25$ & 28 & $33,3 \%$ \\
$26-35$ & 50 & $59,5 \%$ \\
$36-45$ & 6 & $7,1 \%$ \\
\hline SD & 10 & $11,9 \%$ \\
SMP & 17 & $20,2 \%$ \\
SMA & 49 & $58,3 \%$ \\
D3 & 2 & $2,4 \%$ \\
S1 & 6 & $22,1 \%$ \\
\hline P0 & 33 & $39.3 \%$ \\
P1 & 18 & $21.4 \%$ \\
P2 & 22 & $26.2 \%$ \\
P3 & 6 & $7.1 \%$ \\
P4 & 1 & $1.2 \%$ \\
P5 & 3 & $3.6 \%$ \\
P6 & 1 & $1.2 \%$ \\
\hline Jumlah & 84 & $100 \%$ \\
\hline
\end{tabular}

Sumber: Data Primer 2018

Tabel 5.2. Distribusi Frekuensi pengetahuan responden di Puskesmas Mangasa Kota Makassar tahun 2018

\begin{tabular}{llll}
\hline No & Pengetahuan & Frekuensi & $\begin{array}{l}\text { Presentase } \\
(\%)\end{array}$ \\
\hline 1 & Baik & 36 & $42,9 \%$ \\
2 & Kurang & 48 & $57,1 \%$ \\
\hline Jumlah & & 84 & $100 \%$ \\
\hline
\end{tabular}

Sumber, Data Primer, 2018

Tabel 5.3. Distribusi Frekuensi status gizi responden di Puskesmas Mangasa Kota Makassar

\begin{tabular}{llll}
\hline No & Status gizi & Frekuensi $(\mathrm{n})$ & Presentase \\
\hline 1 & Normal & 34 & $40,5 \%$ \\
2 & Tidak normal & 50 & $59,5 \%$ \\
\hline Jumlah & & 84 & $100 \%$
\end{tabular}

Sumber, Data Primer, 2018

Tabel 5.4. Distribusi hubungan pengetahuan dengan status gizi ibu hamil trimester III di Puskemas Magasa Kota Makassar

\begin{tabular}{|c|c|c|c|c|c|c|c|}
\hline \multirow[t]{3}{*}{ Pengetahuan } & \multicolumn{4}{|c|}{ Status gizi } & \multicolumn{2}{|c|}{ total } & \multirow{3}{*}{$\begin{array}{l}\mathrm{P} \\
\text { Value } \\
\end{array}$} \\
\hline & \multicolumn{2}{|c|}{ Normal } & \multicolumn{2}{|c|}{ Tidak normal } & & & \\
\hline & $\mathrm{N}$ & $\%$ & $\mathrm{~N}$ & $\%$ & $\mathrm{n}$ & $\%$ & \\
\hline Baik & 28 & 77,8 & 8 & 22,2 & 36 & 100 & \\
\hline Kurang & 6 & 12,5 & 42 & 87,5 & 48 & 100 & 0,000 \\
\hline Jumlah & 34 & 40,5 & 50 & 59,5 & 84 & 100 & \\
\hline
\end{tabular}

Sumber: Data Primer, 2018 